\title{
Facilitating Building Projects' Short-Term and Long-Term Value Creation
}

\author{
Knut Boge ${ }^{1, *(\mathbb{D})}$, Amin Haddadi ${ }^{2}$, Ole Jonny Klakegg ${ }^{3}(\mathbb{D})$ and Alenka Temeljotov Salaj ${ }^{3}(\mathbb{D}$ \\ 1 Department of Property and Law, Norwegian University of Life Sciences (NMBU), 1433 Ås, Norway \\ 2 Department of Civil Engineering and Energy Technology, Oslo Metropolitan University, 0130 Oslo, Norway; \\ danielam@oslomet.no \\ 3 Department of Civil and Environmental Engineering, Norwegian University of Science and Technology (NTNU), \\ 7491 Trondheim, Norway; ole.jonny.klakegg@ntnu.no (O.J.K.); alenka.temeljotov-salaj@ntnu.no (A.T.S.) \\ * Correspondence: knut.boge@nmbu.no
}

Citation: Boge, K.; Haddadi, A.; Klakegg, O.J.; Salaj, A.T. Facilitating Building Projects' Short-Term and Long-Term Value Creation. Buildings 2021, 11, 332. https://doi.org/ 10.3390/buildings11080332

Academic Editor: Per Anker Jensen

Received: 19 June 2021

Accepted: 22 July 2021

Published: 30 July 2021

Publisher's Note: MDPI stays neutral with regard to jurisdictional claims in published maps and institutional affiliations.

Copyright: (C) 2021 by the authors. Licensee MDPI, Basel, Switzerland. This article is an open access article distributed under the terms and conditions of the Creative Commons Attribution (CC BY) license (https:// creativecommons.org/licenses/by/ $4.0 /)$.

\begin{abstract}
Real estate and buildings are some of facility managers' most costly resources. Thus, knowledge about how to get the most out of building or renovation projects both in the short term and in the long term are of great importance for facility managers. This paper investigates which factors are most important for building and renovation projects' output or short-term value creation, and outcome or long-term value creation, i.e., the completed building's effect for owners and users. Thus, the focus is not primarily financial and the buildings' asset value. The study is based on a national questionnaire survey in Norway (550 respondents). Multivariate statistics (Principal Component Analysis and Linear Multiple Regressions validated with bootstrapping) were used to test the hypotheses. Short-term project management priorities, such as early involvement of technical contractors and FM providers, contract strategy and involvement of owners and users largely decide the qualities of the building, and thus the potential for long-term value creation. The most important factors for long-term value creation, i.e., buildings that facilitate the demand organisation's value creation are the qualities of the completed building, project governance and involvement of owners and users during early phase planning.
\end{abstract}

Keywords: facility management; Corporate Real Estate Management; real estate development; building projects; Norway; project governance; project management; early involvement; valuation; value creation; survey; multivariate statistics; bootstrapping

\section{Introduction}

The European standard EN15221-1:2006 [1] (p. 5) defines Facility Management (FM) as "integration of processes within an organisation to maintain and develop the agreed services which support and improve the effectiveness of its primary activities". A facility is similarly defined as a "tangible asset that supports an organisation" [1] (p. 5). Thus, from the standard's perspective, real estate and buildings are only facilities, and seen from a real estate and building perspective EN15221 is service-centric. The ISO 41000 series, the new global FM standard, has a somewhat broader and more realistic perspective on FM, real estate and buildings. In ISO 41011:2017 [2] (p. 1) FM is defined as an "organizational function which integrates people, place and process [ . . . ] within the built environment [... ] with the purpose of improving the quality [ . . . ] of life of people and the productivity of the core business". Where EN 15221-1 only had facilities, ISO 41011, also introduced the "built environment" defined as "collection of buildings, external works (landscaped areas), infrastructures and other construction works within an area" [2] (p. 3). By recognising the built environment's importance, the ISO41000-series has given real estate and buildings a more prominent position within the field of FM.

Real estate and buildings are some of the most important resources and inputs for facility managers [3]. Real estate and buildings are also some of the most capital-intensive 
and costly undertakings for organisations, particularly if the organisation in question is the owner of the buildings. The foundations for real estate management theory, is "real estate adding value to performance" [4,5]. However, many persons, particularly practitioners, find "added value a complex and ill-defined concept", and what is added value is often determined by the beholder [6] (p. 328). Many practitioners have also asked for a "clear operationalisation of added value" [6] (p. 328).

Geltner et al. [7] (pp. 2-14) distinguish between the space market and the asset market. The space market is the rental market, the market for the right to use a particular property or building, i.e., access to space or areas. The space market is therefore segmented according to the buildings' geographical location and intended use. The asset market is the market for ownership of real estate, as financial investments. The RICS (Royal Institute of Chartered Surveyors) with their IVS (International Valuation Standards) [8] and TEGOVA (The European Group of Valuers' Associations) with their EVS (European Valuation Standards) [9] provide precise and recognised definitions of property value and principles for valuation of real estate for different purposes in the asset market, such as valuation in case of market transactions, rent level, financial reporting and properties or buildings as collateral for mortgages. Valuations of real estate as assets and for financial purposes are typically based on due diligence and financial models based on clearly defined assumptions. Today, most private enterprises lease buildings or parts of buildings. Public administrations often own their buildings but during the last decades leasing of buildings has become more common even for public administrations. Buildings are usually not mobile.

Construction of a new building is one of the most significant Corporate Real Estate Management (CREM) interventions an organisation can do [10] (pp. 15-17). This is also the case for major renovations of existing buildings. However, even involvement in processes where an organisation has signed a long-term lease contract and a landlord erects a new building dedicated to the tenant may expose the tenant organisation to several of the same challenges as a building owner, except that the capital expenditures are smaller. Project governance, policies, functions and roles to control projects and to safeguard positive outcomes for the organisation, and also project management and application of methods and skills to deliver project results, are generally expected to be crucial to facilitate projects' value creation, namely increased worth. We would like to test this presumption. In practice, many project managers still base most of their performance metrics on the so-called iron triangle, i.e., the project's time, cost and quality [11], influencing the project's immediate output (short-term result or value creation) rather than having emphasis on the project's actual outcome (long-term value creation). Thus, project governance and project management can be highly relevant both for facility managers in organisations that have signed a long-term lease contract for a completely new building that is developed for the particular tenant, as well for organisations that own their own buildings, develop new buildings or renovate existing buildings.

An analysis of several articles from different academic fields concerning value and value creation in FM and CREM [12] (p. 69) concluded that "reliable quantitative data are still scarce". Van der Voordt and Jensen [6] (p. 332) gave several recommendations for further research. The most relevant recommendations for this paper were implications of time, i.e., the short and long-term effects of various interventions and lessons to be learned for FM from other disciplines, in this article on project management. The research reported here, based on quantitative data and methods, focuses on construction projects or building projects to be precise. Construction is a special context due to its on-site, one-off production with external resources and fragmented structure with long supply chains [13-15]. Many building owners rarely or seldom invest in new buildings; they are one-time actors. This is even the case for those facility managers who are responsible for a single building or a stable portfolio of buildings. Architects, consulting engineers, construction companies, technical contractors and other professionals take part in large numbers of building projects. Building and renovation projects are thus often characterized by an asymmetry between 
stakeholders. To facilitate value creation for the various stakeholders involved in building projects, project owners as well as project managers must establish project governance and project management that balance the various stakeholders' short and long-term objectives.

This paper presents findings from research that was initiated to develop knowledge from the early design phase to obtain value creation for building owners and users throughout buildings' lifetimes. Given the goal of creating long-term value for owners and users of buildings, this research project has investigated the various stages in building projects; from the strategic, early planning and design phase, through the construction and delivery phases, to the operational phase. The building process may be understood as a kind of relay race, where information and documentation are handed over during the phase transitions to secure the agreed value creation until the operational phase.

One of the learning points from the process of writing Facilities Management and Corporate Real Estate Management as Value Drivers-How to Manage and Measure Adding Value, was to distinguish between adding value to an organisation through FM and/or CREM, i.e., outcome, and adding value to FM and/or CREM processes and products (output) [6] (p. 323). Thus, van der Voordt and Jensen have a different perspective on value and added value than for instance RICS' IVS [8] and TEGOVA's [9] EVS standards for valuation of real estate. Van der Voordt and Jensen's distinction between adding value to an organisation through FM and/or CREM processes and products (output) and adding value to an organisation through FM and/or CREM (outcome) is thus very similar to the distinction in building or renovation projects where the completed building is the output, while the building's utility or benefits for the owners and/or users is the outcome. Thus, Facility Managers who become involved in building or renovation projects must be aware that for a construction company or consulting engineer, completion of the building within time and budget is the project and the ultimate goal. For the Facility Manager, the completed building is just the beginning. For the Facility Manager, the goal is every day to create value for the demand organisation, among others, through provision of buildings that satisfy the users' requirements and facilitate the demand organization's value creation. Turner and Zolin [16] have given a good account this situation, namely that stakeholders' perception of a project's success is not necessarily a question about whether the project was completed within time, cost and with the required quality, but whether the project provides the desired outcome and business objectives.

The short-term value of the building, beyond the economic interest of the parties to get paid for their engagement in the process, is purely potential. It is hypothetic until the building is actually built or renovated and delivered. The efforts by project management and other parties obviously influence the qualities that are built into the building and thus may create low or high potential value depending on how well they accommodate owners' and users' needs and priorities. However, they leave the project before the long-time value is created. The real value comes from using the building, preferably for its intended use, but other uses may also be valuable. Therefore, an office building may contribute not only to an efficient work environment for the immediate uses, but also to a positive or negative perception of the neighborhood by neighbors and visitors.

This study investigates how elements of project management and project governance influence building and renovation projects' value creation. We ask two research questions:

RQ1: Which factors are most important for building project's output or short-term value creation, i.e., the project's time, cost, and the completed building's qualities?

RQ2: Which factors are most important for building project's outcome or long-term value creation, i.e., the completed building's effects for owners and users?

This paper's further structure is first a literature review and a section about conceptual framework and hypotheses, and thereafter materials and methods, results, discussion of the findings and conclusions. 


\subsection{Literature}

In the field of FM, Jensen's [12,17] FM Value Map is a well-known conceptual tool. In the FM Value Map real estate is considered one of several inputs together with facilities, technology, manpower, activities, and know-how. The processes that result in outputs are managed through PDCA (Plan-Do-Check-Act) cycles. The output or provisions are among other basic products such as buildings and spaces, including workplaces, parking, meeting rooms, canteens, etc., and services, which in turn contribute to economic, social, spatial, and environmental outcomes or impacts.

To understand value creation for owners and users of a building, we should start with the term value, which is defined in a variety of ways in different contexts, with the common purpose to focus on customers and users and satisfying their needs. Based on Womack and Jones [18], the real value of goods or service can only be defined by the ultimate customer. However, in the context of building projects, the ultimate customer can be complicated to define. Although this leads us to the individuals using the building as the end users, the fact that every stakeholder has its own perception of value cannot be neglected.

Value creation in a building project depends on three main roles of whom their needs should be assessed: the owner, the suppliers and the users. Haddadi et al. [19] discuss that to create value, the owner's prerequisite can be summarized in profitable/optimal operation of the building and fulfilling the customer's needs. Based on the literature on manufacturing processes, the suppliers are required to minimize waste and non-value creating activities, and to fulfil the customer's (owners and users') needs to create value in the product they have manufactured. The ultimate objective of the project should then be to fulfil the user's needs to increase the "customer's perceived value". The relationships between the project's main roles and their requirements that can contribute to value creation are summarized in Figure 1.

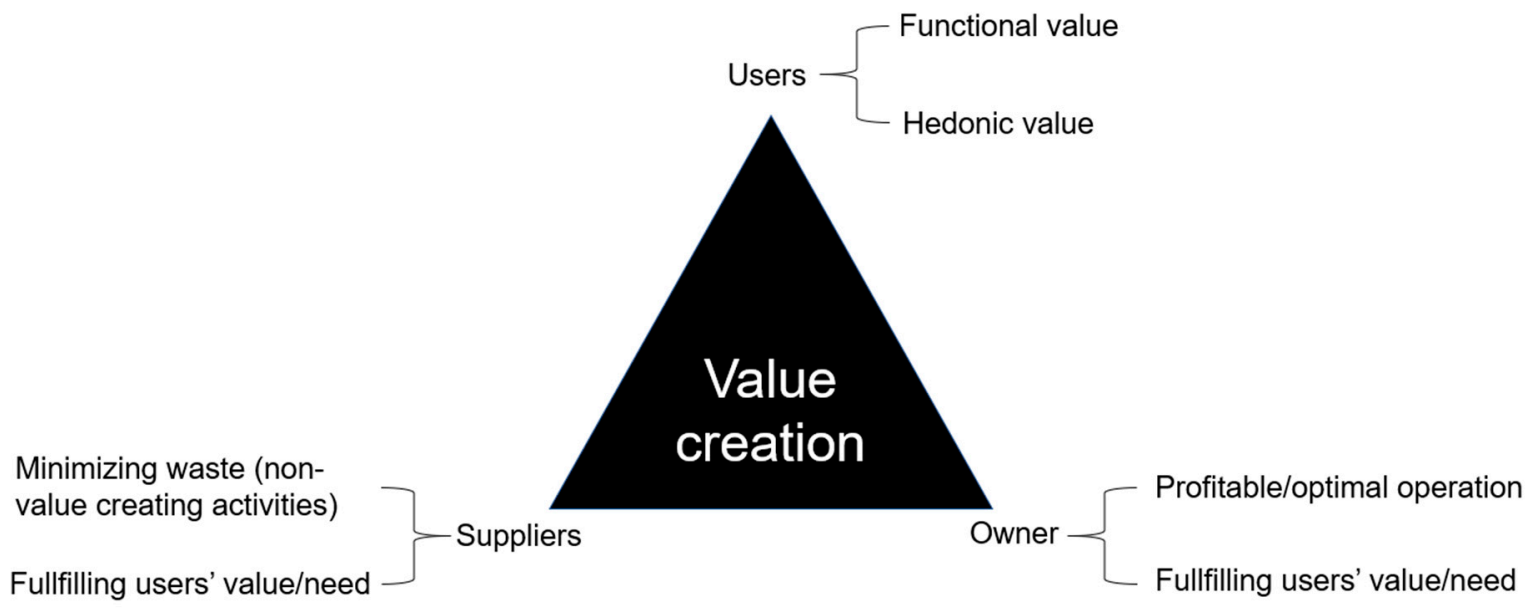

Figure 1. Main stakeholders' requirements for value creation [20].

Seen from an asset and financial perspective, valuation of commercial buildings such as office buildings, factories or store houses is very often based on the income approach, for instance, through application of the capitalisation method or the discounted cashflow (DCF) method [7-9]. A very important implication of the income approach for valuation of commercial buildings is that all other things equal, increased net rent income means a more valuable building, and vice versa. Thus, to make their operations as profitable as possible, financially oriented building owners often strive to maximize rent income from their portfolio of buildings.

The project success is usually linked with the project value [21,22], and perceived differently depending on stakeholder group, social group or individuals. Despite the fact that these elements can contribute to higher satisfaction of user's needs, Arge and Hjelmbrekke [23] argue that projects also must have organizational goals and business 
strategy as reasons for existence. According to Hjelmbrekke et al. [24], project strategies are the missing link in project planning and execution. Bjørberg et al. [25] emphasized the life cycle perspective in the early design phase. Haddadi et al. [19] discussed that value is created when needs are fulfilled and strategic goals are achieved, which means that value creation in a building in a life cycle perspective depends mainly on factors such as "fulfilment of the user's needs" and "fulfilment of owner and the corporate's strategy". Davis [26] concluded that "owner/client" and "user" as stakeholder groups have most success factors in common. The message is, thus, focus on these two stakeholder groups and align their needs for value creation.

Over decades, project management has been defined and redefined. We will return to classics that provide a useful perspective on the definition: Munns and Bjeirmi studied the current definitions of project and project management as basis for discussing project management's role in achieving success. They defined project management simply as "the process of controlling the achievements of the project objectives" [27] (p. 81). Atkinson followed up in the most cited project management article ever. He challenged both the definition of project management and of project success. Project management, he concluded, is better understood as "the definition offered by Turner [ ... ] the art and science of converting vision into reality" [11] (p. 342).

Concerning project governance, in a literature review Ahola et al. [28] distinguish between project governance as external to a specific project and internal to a specific project. Project governance as external to a project is typically found in project-based organizations with principal-agent relations between the organisation and its projects because the project manager may prioritise the project or herself on the organisation's expense. On the other hand, project governance as internal to a specific project aims for projects that meet the various stakeholders' goals and expectations. In the present research, the perspective on project governance is internal to a specific project. Project governance may increase the likelihood of project success $[29,30]$.

In FM there is a gap between theory and practice concerning early-phase planning of buildings. Boge and Temeljotov Salaj [31] and Boge et al. [32] emphasized the earlyphase planning's importance for a building's lifetime value creation. Thus, project value should be specified in the early planning phase, positioned in the project governance strategy, reflected through choice of project delivery model $[33,34]$ and nurtured through project management.

Building qualities is hard to define precisely. Many different perspectives exist, from physical qualities and functional qualities to aesthetical qualities. Aesthetical qualities can for example be defined as three different variables: formal, symbolic and schemas [35]. Winch [36] (p. 55) used "value" as his lens and defined a balance scorecard with four categories: financial value, spatial quality, indoor environmental quality and symbolic quality. These definitions are situational in the sense that they are dependent on what they are intended for. As such, why not go back to the real roots of understanding and use the "Vitruvian values of firmitas (solidity, durability, structure), utilitas (utility) and venustas (beauty, delight)" first formulated by Marcus Vitruvius Pollio, Roman architect (approximately $70 \mathrm{BC}$ ) [37]?

Shenhar and Dvir [38] present an extensive study of the success/failure assessment of building projects based on evaluation of achieving the owner's objectives such as cost, time and quality, for which they state that three measures can provide an indication of success or failure, but not a proper picture of the long-term performance of the project. They introduce business results and preparing for the future as new success criteria. Turner and Zolin [16] stress that success, particularly in large project, should be assessed not only based on the different stakeholders' perspectives but also over different timescales. Turner and Zolin's [16] argument about timescale reflects Chan et al. [39] discussion of trends in measuring project success. Chan et al. [39] concluded that project performance has been a topic of great interest for scholars recently and present three trends in measuring project success: 
- Meeting objectives: Achieving client's objectives, both tangible (time, cost, quality) and less tangible criteria.

- Global Approach: Considering project success criteria from both subjective and objective perspectives.

- Beyond project: Considering positive effects brought about by the project and tangible means.

These trends suggest that a building project's success should be assessed with a life cycle perspective considering outcomes of the project, rather than just the short-term project perspective. Authors, such as Spencer and Winch [40], stressed an increased emphasis on building life-time costs influenced by using a value management approach during the design and development process; Morris [41] discussed achieving an objective during a defined life cycle. Breese [42] discusses the realization of benefits towards achieving the business objectives as a flawed process with a variety of issues and obstacles. Hjelmbrekke and Klakegg [43] emphasized that building projects have traditionally been based on project organizations that leave the users in a half-excluded/part-included position. The fact that value creation arises through future users and the importance of recognizing customer expectation in the pre-design phase leads us to the predesign phase's importance for value creation in projects.

Based on ideas from Professor Jeffrey Pinto, Samset [44] introduced tactical and strategic performance in construction projects. Tactical performance concerns delivering the agreed project outputs on time and within cost, and strategic performance includes longerterm perspectives, such as relevance, effect and sustainability. Arge and Hjelmbrekke [23] pointed out that working towards enhancing strategic performance (outcome focus) would enhance value for project owners and users.

According to Leiringer and Bröchner [45], the building industry is changing its focus from cost efficiency to added value, and this shift broadens the building industry's scope from product delivery to design, production and even FM. One implication of this shift is an increased importance of early-phase planning to improve the construction industry's ability to satisfy the clients' needs. Gottlieb and Haugbølle [46] suggested fundamental dynamics of collaboration in building industry could be understood as three activity systems of production, values, and interest. The activity system of values institutionalizes creation and maintenance of culture, community and professional identity. Culture, community, and professional identity in turn are important determinants for early-phase planning. El. Reifi and Emmitt [47] found that design time is one of the factors that seriously hinder development of design value. Other obstacles are lack of early contractor involvement, poor communication and management, the design team's attitudes and their ability to understand the clients' goals. The design is highly consequential for the buildings' ability to meet the clients and users' needs during the use phase. Even Wondimu et al. [48] concluded that early contractor involvement is beneficial for projects' value creation, but early contractor involvement may conflict with rules regulating public procurements. Thus, public procurement regulations may have side effects concerning building projects value creation.

Thus, project governance and project management issues may represent significant obstacles for value creation and success in building projects. Middle management is in a key position as an information filter and action provider in any organization [49]. When the middle management level or project management does not provide relevant information or is unable to take adequate action, value creation immediately suffers. In terms of governance, the Board of Directors are responsible for the wellbeing of the organization and all its ongoing activity, including all projects. However, they are often not close to those projects and need a dedicated representative to follow them up and oversee the development in portfolios, programs, and projects. This role is termed project executive or project sponsor [50].

Contract strategy in projects is defined as "the division of the project into separate contracts, and the form and the conditions of the contract most likely to encourage satisfac- 
tory completion, whilst providing controls and opportunities to the owner or contractor to rectify problems before they cause serious difficulty to the project" [51] (p. 74). The contract strategy may thus influence project performance [52]. Watermayer puts contract strategy into the bigger concept of procurement strategy and defines: "Procurement strategy is all about the choices made in determining what is to be delivered through a particular contract, the procurement and contracting arrangements and how secondary procurement objectives are to be promoted" [53] (p. 223). Contract strategy is an important tool for most Facility Managers.

The literature review shows the recent years' growing and more specific focus on value creation in the construction field, but the knowledge about value creation in building projects is more developed in theory than in practice. Thus, our study of practitioners' perception of which factors that facilitate value creation in building projects addresses a topic where there is lack of evidence, even if most practitioners have rather clear ideas about what is value and what is not.

\subsection{Conceptual Framework and Hypotheses}

We designed a conceptual framework (Figure 2) to investigate the respondent's perception of what matters for building projects' short-term and long-term value creation. We divided into short- and long-term goals and both include project governance and project management process perspectives. Three main groups of parameters are important for the building process (planning, design, and execution): situational parameters, resources, and strategies and choices. The first two (situation and resources) are specific to each single case project and thus not directly included in this study. Our analysis includes strategies and choices made (through the whole lifecycle) and will mirror the respondents experience from a large number of cases, indirectly including situational parameters and resources.

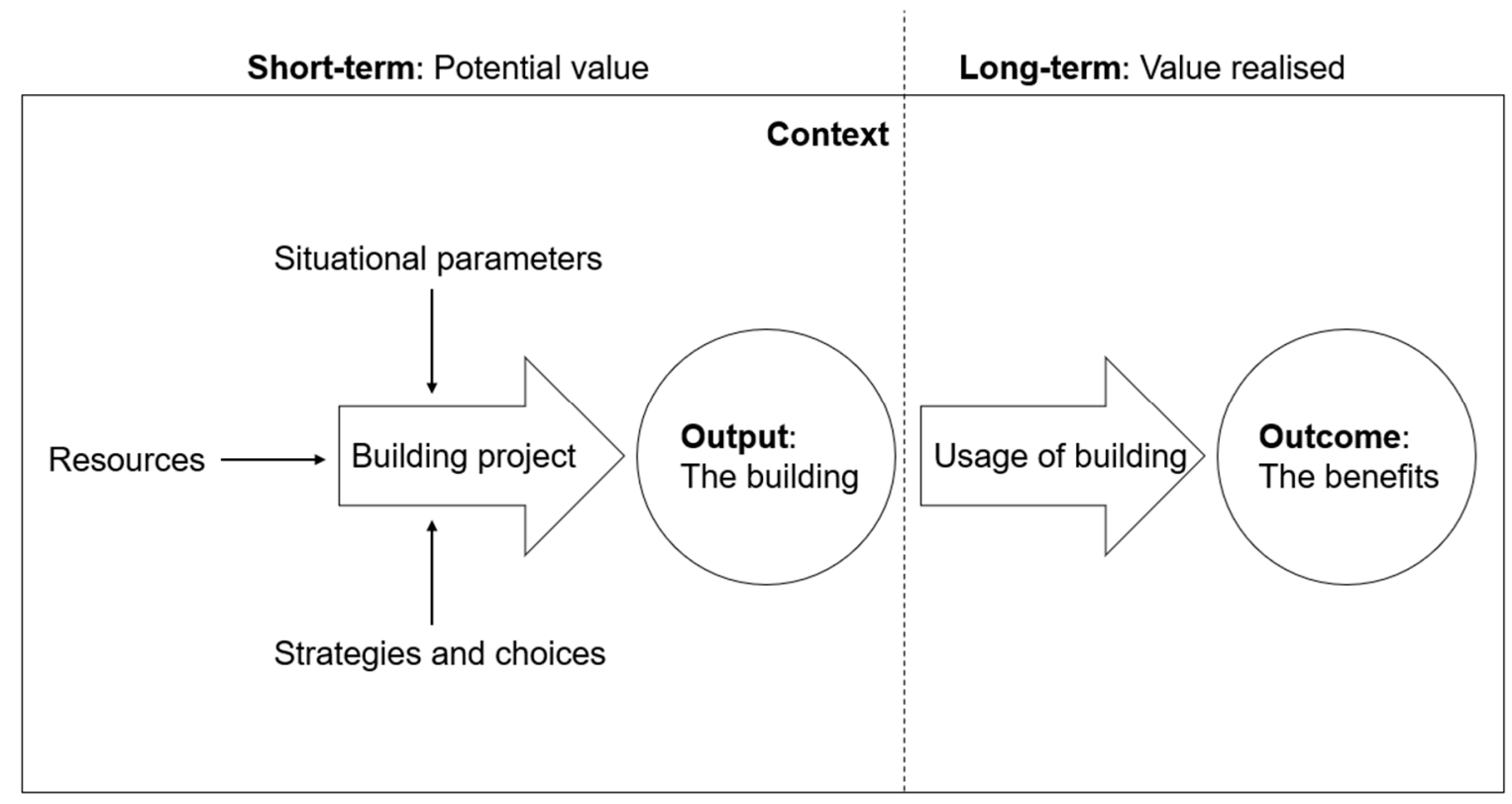

Figure 2. Conceptual framework.

The short-term value of the building, beyond the economic interest of the parties to get paid for their engagement in the process, is purely potential. It is hypothetic until the building is built and delivered. The efforts by project management and other parties obviously influence the qualities that are built into the building and thus may create low or high potential value depending on how well they accommodate owners' and users' needs and priorities. However, they leave the project before the long-time value is created. The real value comes from using the building, preferably for its intended use, but other uses may also be valuable. Therefore, an office building may contribute not only to efficient 
work environment for the immediate uses, but also a positive or negative perception of the neighborhood by neighbors and visitors.

To facilitate building projects that provide long-term value creation, long-term value creation needs to be in focus from the start. Project owner's project governance very much determines the regulatory framework and operating parameters for a building project's project management. However, in terms of logical sequence, the potential for value creation must be developed and built before the use value or return on investment can be realized. Thus, we start by questioning which factors are most important for project output.

Based on RQ1 and the literature review, we derived several hypotheses about which factors are most important for the building project's output or short-term value creation, such as the project's time, cost, and the completed building's qualities:

Hypothesis 1A (H1A). Project management is positively related to the completed building's qualities.

Hypothesis 1B (H1B). Early involvement of technical contractors is positively related the completed building's qualities.

Hypothesis $1 \mathrm{C}(\mathrm{H} 1 \mathrm{C})$. Early involvement of FM providers is positively related to the completed building's qualities.

Hypothesis 1D (H1D). Having a contract strategy is positively related to the completed building's short-term qualities.

Hypothesis 1E (H1E). Involvement of owners and users during the construction phase is positively related to the completed building's qualities.

Building qualities need to be understood in a wide sense. It includes not only architecture, design, and technical qualities, but all functions, capabilities and flexibility for users and operators.

Then we question what factors can give successful value creation in the long-term perspective. Based on RQ2 and the literature review, we derived several hypotheses about which factors are most important for the building project's outcome and long-term value creation, i.e., the completed building's effects for owners and users:

Hypothesis 2A (H2A). Project governance is positively related to the completed building's longterm value-creation.

Hypothesis 2B (H2B). The completed building's qualities are positively related to the completed building's long-term value creation.

Hypothesis $2 \mathrm{C}(\mathbf{H} 2 \mathrm{C})$. Project objectives are positively related to the completed building's longterm value creation.

Hypothesis 2D (H2D). Involvement of owners and users in early phase planning is positively related to the completed building's long-term value creation.

These long-term perspectives can only become successful if the right results are developed in the short-term perspective, even if there are exceptions and examples of unintended successes. One of the most prominent such examples is the Opera House in Sydney, which failed almost every possible short- and long-term objective, but still, incidentally, created a global-scale tourist magnet. However, projects such as the Opera House in Sydney are very unusual exceptions. 


\section{Materials and Methods}

A deductive approach was chosen to accommodate existing theory and new empirical evidence. The research design is a cross-sectional large $\mathrm{N}$ observational design [54] (pp. 118-124), where the variations in the explanatory variables are analysed across units but not across time. Cross-sectional designs are robust and one of the most common research designs in social sciences.

\subsection{Development of Questionnaire}

Several students have been involved in parts of the project and made valuable contributions. The questionnaire was developed through literature studies and findings from students' bachelor, master and $\mathrm{PhD}$ thesis, and the questions were validated through a series of workshops and meetings with the research consortium's partners, and discussions with stakeholders from the construction and FM industry. Involvement of stakeholders and pretesting clearly improved the data's validity.

The questionnaire consists of five sections. The first was about the respondents (demographic data) and project data (size, respondent's role, delivery model). Section 2 investigated the building owner's priorities in the particular project; measurement of deliveries against functional and performance requirements; whether the owner's specific and measurable requirements governed decisions; owner involvement; user involvement; early involvement of FM competencies; project management and early involvement of technical contractors. Section 3 was about phase transitions and decision-making processes. Section 4 was about the respondent's experiences with the completed building, effects of the project and the completed buildings' perceived value creation for owners and users. Section 5 was about perceived success factors. The present study emphasizes questions in the questionnaire's Sections $2-5$, where each question could be answered on a six-item Likert scale from 1 (disagree completely) to 6 (agree completely), or the alternative "Don't know/Not relevant".

\subsection{Data Collection}

The study population was Norwegian professional practitioners who have been involved in planning and construction of buildings, distributed via web-link to member organizations from the Norwegian Consulting Engineer's Association, the National Association of Norwegian Architects, and the Norwegian Facilities Management Association, and to the research project consortium. The estimated population of possible respondents was approximately 8500 persons. The data collection took place between June and September 2016, and 1034 respondents answered the survey. After cleansing respondents with more than 20 percent missing answers on the questions with six-item Likert scales, the effective sample was reduced to 550 respondents and had very few missing answers (genuine non-response) in most questions, which increases the likelihood for unbiased data.

\subsection{Analytical Methods}

The data were analysed by IBM SPSS Statistics version 27 . When making multivariate statistical analyses of data with a Likert scale supplemented with alternatives such as "Don't know/Not relevant" which are not part of the Likert scale, it is common practice to code such alternatives outside the Likert scale (for instance as 9) to differentiate these answers from genuine non-response (often coded as 99) in the analyses, and because calculations of statistical measures such as mean, standard deviation, etc., are based on the Likert scale. Small shares of non-response will usually not distort multivariate analyses. However, if the data have large shares of non-responses, either because of genuine nonresponse or many "Don't know / Not relevant" answers, then it is very useful to know which categories of respondents have not responded or responded "Don't know/Not relevant" for a particular question. To maintain control of non-responses, crosstabulations and other descriptive analyses were made of each question prior to the multivariate analyses 
to assess which categories of respondents that had not responded or answered, “Don't know/Not relevant".

Exploratory principal component analysis (PCA) was used to combine information from several Likert scales questions (items) into a smaller set of components (constructs or composite variables) with the smallest possible loss of information [55] (p. 94). Components based on two or more items also provide more robust measures than individual items and reduce measurement errors [55] (p. 96 ff.). The derived component matrix was rotated with Varimax rotation because rotation may simplify the interpretation. Orthogonal rotation, such as Varimax, maximizes the components' variance and usually provides clear separation of the components [55] (p. 113). It is common to report only items with component loadings $>0.30$. Component loadings of \pm 0.50 are considered practically significant, and the aim of any PCA or factor analysis is loadings $>0.70$, because component loadings $>0.70$ provide significant results with as small samples as 60 [55] (pp. 114-115). The derived components have been linked to theoretical concepts discussed in the literature review.

Use of multi-item scales (constructs or indexes) compared to single variables also improve the validity, i.e., that scales measure what they are supposed to measure [55] (p. 8). Construct $\mathrm{C} 1$ to $\mathrm{C} 10$ were defined as new variables in SPSS by adding the scores for those questions with component loadings $>0.30$ on the component in question and calculating each respondent's mean score for the component. The scores for questions with component loadings on more than one component were excluded if the separation between the components were less than approximately 0.30 . Construct validity was ensured through pilot testing and unrotated factor analysis (PCA). The constructs' reliability has been assessed through calculations of Cronbach's alpha [55] (p. 90). To investigate the two research questions, based on the literature review, initial examination of the data and the analytical model in Figure 2, several hypotheses were derived. These hypotheses have been tested with multiple linear regressions which facilitates control of the effect of the other factors included in the model.

Hair et al. [55] (pp. 22-24) recommends to always validate the results from multivariate analysis and recommends three different validation methods. The fist is to split the sample and use one subsample to estimate the model and the other to validate the model. The second method is to collect an additional sample to validate the model. The third method is to use bootstrapping. Bootstrapping means that SPSS draws a large random sample with replacement (bootstrap sample) from the respondents' answers to the questions included in the model [56] (p. 199), to assess if the bootstrapping parameters' (B) confidence intervals does not include zero. The estimated bootstrapping parameters are significant if they are different from zero [55] (p. 22). In the present research, bootstrapping has been used to validate the linear multiple regression analyses that were used to test the hypothesis.

\subsection{The Respondents}

The 550 respondents' age varied between 26 and 90 years. The respondents' mean and median ages were 52 and 53 years respectively. Respondents had education backgrounds in engineering (449), business administration (137), architecture (54), finance and investment, or law (23), marketing and communication (21) and social science (12). Several respondents had more than one education. All in all, these respondents well represented those involved in Norwegian building projects.

The respondents could choose more than one role. Table 1 shows the respondents represent a wide range of roles involved in building projects, which also indicates a representative sample. The respondents had from 1 to 65 years' experience in their roles, and the mean number of years in a role was 16 years. Thus, most respondents were experienced. The respondents' answers were based on different kinds of building projects: new building (352), refurbishment and renovation of existing buildings (254), and extension or appendage of existing buildings (122). Thus, some of the building projects included more than one activity. 
Table 1. The respondents' roles in their projects.

\begin{tabular}{cc}
\hline Role & N \\
\hline Building owner's project manager & 197 \\
Building owner & 141 \\
Consultant engineer & 107 \\
Internal project manager & 65 \\
Steward or building manager & 60 \\
Construction manager & 43 \\
Project group manager & 42 \\
User & 31 \\
Others & 26 \\
Construction contractor & 28 \\
Construction contractor's project manager & 28 \\
Architect & 23 \\
FM service provider (internal or external) & 16 \\
Technical contractor & 9 \\
\hline
\end{tabular}

The building projects' total cost inclusive value added tax (VAT) was divided into three categories: 0-150 million NOK (MNOK) (approximately 0-15 million Euro or 0 to 17.5 million USD), 150-700 MNOK (approximately 150-70 million Euro or 17.5 to approximately 82 million USD) and more than 700 MNOK (MNOK) (more than 70 million Euro or 82 million USD), and "don't know". The findings indicate the sample of respondents very well represent the current Norwegian construction market. About 80 per cent of the 549 projects have a total cost less than 150 MNOK (219 respondents), or between 150 and 700 MNOK (211 respondents). About one fifth of the projects (107 respondents) have total costs above 700 MNOK. 12 respondents did not know their projects' total cost.

Regarding type of project ownership, respondents reported the building in the project they have based their answers on is owned by a private enterprise (217), a municipality or county municipality (146), a hybrid organisation (95) and a government body (40). A hybrid organisation is an organisation owned by a public administration and serving the common good but operating almost as a private enterprise.

The answers regarding kind of projects show the respondents' answers are based on a standard building with known solutions (323), a technically complex building (163) and an aesthetically or otherwise unique signal building (149). Some buildings, for instance signal buildings, may also be technically complex buildings.

The respondents have often been involved in more than one phase in the project their answers are based on. Respondents have been actively involved in the early phase (318), the project planning and design phase (437), in the construction phase (427), and in the operational/use phase (188). Thus, most respondents have been involved in the project planning and construction phases.

Table 2 shows that offices or business facilities, primary and secondary schools and housing are the respondents' volume projects. Table 2 also shows the distribution of standard buildings, technically complex buildings, and signal buildings. The respondents could choose more than one category of buildings, because some projects are complex and include more than one category of building. Many cultural facilities are, for instance, technically complex signal buildings. 
Table 2. The respondents' building projects.

\begin{tabular}{ccccc}
\hline Building Category & $\begin{array}{c}\text { Total Number } \\
\text { of Buildings }\end{array}$ & $\begin{array}{c}\text { Standard } \\
\text { Buildings }\end{array}$ & $\begin{array}{c}\text { Technically } \\
\text { Complex } \\
\text { Buildings }\end{array}$ & $\begin{array}{c}\text { Signal } \\
\text { Buildings }\end{array}$ \\
\hline Office and business & 201 & 115 & 63 & 66 \\
Schools & 94 & 74 & 17 & 16 \\
Housing & 86 & 71 & 12 & 20 \\
Assisted living & 65 & 50 & 13 & 11 \\
Hospitals & 54 & 22 & 38 & 7 \\
Higher education & 51 & 18 & 24 & 20 \\
and research & 49 & 15 & 15 & 31 \\
Culture facilities & 34 & 22 & 13 & 12 \\
Sports facilities & 3 & 0 & 2 & 1 \\
Prisons & & & & \\
\hline
\end{tabular}

\section{Results}

This section presents the findings. The structure is first PCA to derive the constructs, thereafter analysis of the constructs and finally linear multiple regressions to test the hypotheses concerning which factors in building projects facilitate output or short-term value creation and which factors facilitate outcome or long-term value creation. The two regression models were validated with bootstrapping.

\subsection{Principal Component Analysis}

Data from the questionnaire's part about the completed building and other outcomes of the project, which had 10 questions, each with 6 item Likert scales from 1 (disagree completely) to 6 (agree completely) and "Don't know /Not relevant", about the completed building (3 questions) and outcomes of the project (7 questions) were suitable for PCA. This is because KMO's measure of sampling adequacy was 0.893, and Bartlett's test of sphericity gave an approximate $\chi^{2}(45,914.859), p<0.001$. Table 3 shows the rotated component matrix.

Table 3. Rotated component matrix-experiences with the completed building-positive effects from the project.

\begin{tabular}{ccc}
\hline Rotated Component Matrix ${ }^{\text {a }}$ & \\
\hline Item & \multicolumn{1}{c}{ Component } \\
\cline { 2 - 3 } Market position & C1 & C2 \\
\hline Reputation & $\underline{\mathbf{0 . 8 2 9}}$ \\
\hline Innovation & $\underline{\mathbf{0 . 7 9 9}}$ \\
\hline Productivity and effectiveness & $\underline{\mathbf{0 . 7 4 3}}$ \\
\hline Contributed to achievement of strategic goals & $\underline{\mathbf{0 . 7 1 0}}$ & 0.338 \\
\hline Profitability & 0.664 & 0.414 \\
\hline Development of own competencies & 0.574 & 0.469 \\
\hline Technical systems and integration between systems worked as described & 0.541 & 0.512 \\
\hline The project satisfies the value areas' expressed requirements (function, \\
performance) & $\underline{\mathbf{0 . 8 7 4}}$ \\
\hline Training of the operational staff to optimize the operations & $\underline{\mathbf{0 . 8 5 0}}$ \\
\hline Extraction Method: Principal Component Analysis. Rotation Method: Varimax with Kaiser \\
\hline Normalization.
\end{tabular}


PCA gave two components which explain 66.7 per cent of the variance: component C1 Projects outcomes $(\alpha=0.82)$ and component C2 Completed building's qualities $(\alpha=0.88)$. Thus, both components have acceptable reliability $(\alpha>0.70)$.

Prior to the PCA there were made crosstabulations of each question to investigate the non-response because of genuine non-responses and the coding of "Don't know/Not relevant". The question in component $\mathrm{C} 1$ about the outcome of the project about market position as positive effect for the organization that accomplished the project had 431 valid answers (8 non-responses and 111 "Don't know/Not relevant" answers). The most important categories of respondents who answered "Don't know/Not relevant" were building owners' project managers (56), building owners (39) and stewards or building managers (22). The question in component $\mathrm{C} 1$ about productivity and effectiveness as positive effects of the project had 482 valid answers (6 non-responses and 62 "Don't know/Not relevant" answers). The most important categories of respondents who answered "Don't know/Not relevant" were building owners' project managers (25), building owners (20), consulting engineers (11) and internal project managers (11). The question in C1 about innovation had had 356 valid answers (165 non-responses and 29 "Don't know/Not relevant"). The most important categories of respondents that chose not to answer this question about innovation as positive effect of the project were building owners (141), building owners project managers (43), stewards or building managers (36), users (31) and internal project managers (23). The respondents could choose more than one role; therefore the different roles' numbers of non-responses can be higher than the actual number of non-responses. The respondents' answers concerning the outcome of the project may indicate that many building owners, their project managers, stewards and building managers are more financially oriented than concerned with the outcomes of building and renovation projects. The consultant engineers may similarly be more interested in the planning and construction process than in the outcome.

In component $\mathrm{C} 2$ about the project's output, the question about whether the technical systems in the completed building and the integration between the building's technical systems worked as supposed had 367 valid answers (145 non-responses and 38 “Don't know/Not relevant"). The most important categories of respondents that had not answered this question were again consulting engineers (45), building owners' project managers (40), building owners (32) and project group managers (16). The most import categories of respondents that chose "Don't know/Not relevant" were building owners' project managers (14), consulting engineers (13), architects (6) and building owners (5). The question in component $\mathrm{C} 2$ about whether the project (the completed building) satisfied the value areas' expressed requirements had 363 valid answers (145 non-responses and 42 "Don't know/Not relevant"). The most important categories of respondents that choose not to answer this question were again consulting engineers (45), building owners' project managers (40), building owners (32), project group managers (16) and internal project managers (9). The most import categories of respondents that chose “Don't know / Not relevant" were building owners' project managers (15), consulting engineers (13) and building owners (6). Component C2's question about training of the operational staff to optimize the operations had 351 valid answers ( 145 non-responses and 54 "Don't know / Not relevant"). The most important categories of respondents who choose not to answer this question were again consulting engineers (45), building owners' project managers (40), building owners (33), project group managers (16), and internal project managers (9). The most important categories of respondents who chose "Don't know/Not relevant" were consulting engineers (20), building owners' project managers (16), architects (10), and building owners (7). These answers may indicate that many building owners and their representatives are more financially oriented than concerned with the projects' output. For those who are financially oriented, one of the main parameters concerning office or factory buildings is the annual net rent income, due to the annual net rent income's importance for a building's value as collateral or resale value. 
The questionnaire's part concerning the project owner's priorities had 15 questions with six-item Likert scales ( $1=$ disagree completely, $6=$ agree completely) and "Don't know/Not relevant". The questions investigated the building owner's involvement in the decision making process concerning value areas given specific and measurable requirements (three questions); user involvement concerning choice of solutions influencing their functional or performance requirements (three questions); involvement of FM providers to safeguard operational matters (three questions); the project manager's priority of the building owner's measurable requirements (three questions); and involvement of technical contractors (three items). These data were suitable for PCA, because KMO's measure of sampling adequacy was 0.747 and Bartlett's test of sphericity gave an approximate $\chi^{2}$ $(105,3512.482), p<0.001$.

PCA of the questionnaire's part two about the project owner's priorities gave five components, which explain 77.0 per cent of the variance. Table 4 shows the rotated component matrix. These five components C3 Project management $(\alpha=0.88)$, C4 Early involvement of FM providers $(\alpha=0.88)$, C5 Involvement of owners and users during construction phase $(\alpha=0.74), C 6$ Early Involvement of technical contractors $(\alpha=0.78)$, and C7 Involvement of owner and users during early phase planning $(\alpha=0.71)$ have acceptable reliability $(\alpha>0.70)$.

Table 4. Rotated component matrix-The project owner's priorities.

\section{Rotated Component Matrix ${ }^{a}$}

\begin{tabular}{|c|c|c|c|c|c|}
\hline \multirow{2}{*}{ Item } & \multicolumn{5}{|c|}{ Component } \\
\hline & C3 & C4 & C5 & C6 & C7 \\
\hline Building owner's project manager-Planning phase & 0.867 & & & & \\
\hline Building owner's project manager-Construction phase & $\underline{0.778}$ & & 0.323 & & \\
\hline Building owner's project manager-Early phase & $\underline{0.774}$ & & & & 0.390 \\
\hline FM provider involvement-Planning phase & & 0.861 & & & \\
\hline FM provider involvement-Construction phase & & 0.805 & 0.366 & & \\
\hline FM provider involvement-Early phase & & $\underline{0.735}$ & & & 0.419 \\
\hline Owner involvement-Construction phase & & & 0.802 & & \\
\hline User involvement-Construction phase & & & $\underline{0.719}$ & & \\
\hline Owner involvement—Planning phase & 0.364 & & $\underline{0.713}$ & & 0.300 \\
\hline Technical contractor actively involved-Planning phase & & & & $\underline{0.916}$ & \\
\hline Technical contractor actively involved-Early phase & & & & $\underline{0.840}$ & \\
\hline Technical contractor actively involved-Construction phase & & & 0.342 & $\overline{0.670}$ & \\
\hline User involvement-Early phase & & & & & 0.838 \\
\hline User involvement-Planning phase & & 0.380 & 0.448 & & $\underline{0.611}$ \\
\hline Owner involvement-Early phase & 0.327 & & 0.347 & & $\underline{0.576}$ \\
\hline
\end{tabular}

Extraction Method: Principal Component Analysis. Rotation Method: Varimax with Kaiser Normalization.

a Rotation converged in six iterations.

The three questions in component $\mathrm{C} 3$ about project management concerning involvement of the Building owner's project manager in the planning, construction, and early phases, had approximately 500 valid answers each and 3 genuine non-responses each. Most of the "Don't know /Not relevant" answers came from Consulting engineers (varying between 12-28 such answers in the three questions). These "Don't know /Not relevant" answers are interesting, because according to the literature review project management is assumed to facilitate the completed building's qualities.

In component $\mathrm{C} 4$ about FM, the three questions about involvement of FM suppliers in the planning, construction, and early phases (452-475 valid answers and 3 genuine non-responses in each question), there were 72 "Don't know/Not relevant" answers in the planning phase, 94 in the construction phase, and 95 in the early phase. The most important categories of respondents that answered "Don't know/Not relevant" concerning the involvement of FM suppliers were consulting engineers (25, 40 and 29 in the respective 
phases), building owners' project managers (19, 22 and 24 in the respective phases), building owners (10, 13 and 12 in the respective phases), and construction company's project managers ( 9,8 and 12 in the respective phases) indicate that FM is not necessarily some consulting engineers, building owners and construction companies' main concern, even if early involvement of FM competencies can facilitate more FM-friendly buildings and reduced operational costs.

In component $\mathrm{C} 5$ about owner and user involvement in the construction phase, the three questions had between 489 and 528 valid answers and 3 genuine non-responses in each question. The most important categories of respondents that answered "Don't know /Not relevant" in these three questions were again consulting engineers $(23,24$, and 5 in the respective questions) and building owners' project managers $(6,12$, and 2 in the three questions). The other "Don't know/Not relevant" answers were evenly distributed across the other categories of respondents.

In component $\mathrm{C} 6$ about involvement of technical contractors, the three questions had between 483 and 510 valid answers and each question had 4 genuine non-responses. The most important categories of respondents that answered "Don't know/Not relevant" were again consulting engineers (12,18 and 26 in the respective categories), building owners' project manager $(5,10$, and 9 in the respective questions), and building owners $(8,8$ and 12 in the respective questions). These "Don't know / Not relevant" answers are interesting because technical contractors can facilitate innovations in building and renovation projects.

In component $\mathrm{C} 7$ about involvement of owners and users in early phase planning, the three questions had between 501 and 519 valid answers and 3 non-responses in each question. The most important categories of respondents that answered "Don't know/Not relevant" in the three questions were again consulting engineers $(13,8$, and 11 in the respective questions) and building owners' project managers $(12,8$ and 8 in the respective questions). The other "Don't know/Not relevant" answers were evenly distributed across the other respondents. These "Don't know /Not relevant" answers are interesting because the involvement of owners and users increases the likelihood of development of buildings aligned to the users' needs, i.e., buildings that facilitate value creation.

The questionnaire's part five about success factors and obstacles concerning the building owners and users' goal attainment in the project included 14 questions with 6 item Likert scales ( $1=$ disagree completely, $6=$ agree completely) and "Don't know $/$ Not relevant". These data were suitable for PCA, because KMO's measure of sampling adequacy was 0.870 and Bartlett's test of sphericity gave an approximate $\chi^{2}(91,1332.215), p<0.001$.

PCA of the questionnaire's part about success factors and obstacles concerning the building owners and users' goal attainment gave 3 components, which explain 61.2 per cent of the variance. Table 5 shows the rotated component matrix. The three components C8 Project objectives $(\alpha=0.82)$, C9 Project governance $(\alpha=0.75)$ and C10 Contract strategy $(\alpha=0.86)$ have acceptable reliability $(\alpha>0.70)$.

In component $\mathrm{C} 8$ about project objectives the five questions about environmental certification, innovation, life cycle costs, competitive tenant costs and co-location of actors in the project phases had between 297 and 462 valid answers. The five questions had 10 non-responses each, the remaining missing answers were "Don't know / Not relevant". The most important categories of respondents that answered "Don't know/Not relevant" in the five questions were again building owners' project managers $(29,31,19,84$, and $27)$, consulting engineers $(25,16,23,55$ and 19), building owners $(17,15,11,52$, and 21$)$. The remaining "Don't know/Not relevant" answers were relatively evenly distributed across the other respondents. The building owners' project managers, the building owners and even the consulting engineers were clearly most skeptical to competitive tenant costs. They were also skeptical to environmental certification and innovations. The fact that rent income is one of the most important parameters concerning a building's market value and value as collateral may explain the building owners and their representatives' skepticism to competitive tenant costs, but their skepticism to environmental certification 
and innovations represents a puzzle since environmental certification and innovations may increase the value of a building.

Table 5. Rotated component matrix-Success factors and obstacles concerning attainment of the building owners' and the users' objectives.

\begin{tabular}{|c|c|c|c|}
\hline \multicolumn{4}{|l|}{ Rotated Component Matrix ${ }^{a}$} \\
\hline \multirow{2}{*}{ Item } & \multicolumn{3}{|c|}{ Component } \\
\hline & $\mathrm{C} 8$ & C9 & C10 \\
\hline Environmental requirements (certification of the completed building) & $\underline{0.794}$ & & \\
\hline The building owner's willingness to invest in innovations & $\underline{0.782}$ & & \\
\hline Life cycle costs & $\underline{0.737}$ & & \\
\hline Competitive tenant costs (lease and operational costs) & $\underline{0.655}$ & & \\
\hline Co-location of actors in the project phases & $\underline{0.616}$ & & \\
\hline Description and functional requirements from the early phase & & $\underline{0.756}$ & \\
\hline Building owner and project manager's competencies and experience & & $\underline{0.726}$ & 0.305 \\
\hline Owner's involvement & & $\underline{0.677}$ & \\
\hline Users' involvement & & $\underline{0.676}$ & \\
\hline Building contractor's project manager's competencies and experience & & 0.674 & 0.436 \\
\hline Transfer or responsibilities and information during phase transitions & 0.479 & 0.563 & \\
\hline Building contract & & & $\underline{0.857}$ \\
\hline Tender process & & & $\underline{0.829}$ \\
\hline Investment budget & 0.305 & & $\underline{0.631}$ \\
\hline
\end{tabular}

Extraction Method: Principal Component Analysis. Rotation Method: Varimax with Kaiser Normalization.

${ }^{a}$ Rotation converged in 5 iterations.

In component $\mathrm{C} 9$ about project governance, the four questions about descriptions and functional requirements from the early phases, the building owner and project manager's competencies, owner's involvement and users' involvement had between 512 and 531 valid answers. Each question had 10 non-responses; the remaining missing answers were "Don't know/Not relevant". The most important categories of respondents that answered "Don't know/Not relevant" were again consulting engineers $(6,5,6$, and 10) and building owners' project managers $(3,1,4$, and 8$)$.

In component $\mathrm{C} 10$ about contract strategy, the three questions about building contract, tender process and investment budget had between 480 and 501 valid answers, and the three questions had 10 non-responses each. The remaining missing were "Don't know/Not relevant" answers. The most important categories of respondents that answered "Don't know/Not relevant" in the three questions were Consulting engineers $(19,26$, and 14), Internal project managers $(6,7$, and 6$)$, Users $(6,10$, and 7$)$, and Building owners $(5,13$, and 4).

\subsection{The Constructs and Their Associations}

Table 6 provides an overview of the 10 constructs derived through PCA, hereunder the constructs' bivariate correlations (Pearson's Rho) and reliability (Cronbach's alpha), which is shown on the table's diagonal, and the constructs' mean, standard deviation (SD) and number of observations (N), which is shown in the bottom rows. Pierson's Rho (r) is a measure of effect size, i.e., the magnitude of a phenomenon. According to Cohen [57], $r=0.50$ indicates a large effect size, $r=0.30$ indicates a medium effect size and $r=0.10$ indicates a small effect size. 
Table 6. The constructs' correlation matrix.

\begin{tabular}{|c|c|c|c|c|c|c|c|c|c|c|c|}
\hline Construct $/ \alpha$ & & $\mathrm{C} 1$ & $\mathrm{C} 2$ & $\mathrm{C} 3$ & $\mathrm{C} 4$ & C5 & $\mathrm{C} 6$ & C7 & $\mathrm{C} 8$ & C9 & C10 \\
\hline \multirow{2}{*}{ C1 Project outcomes } & $\mathrm{r}$ & 0.82 & & & & & & & & & \\
\hline & $\mathrm{N}$ & 302 & & & & & & & & & \\
\hline \multirow{2}{*}{$\begin{array}{l}\text { C2 Completed building's } \\
\text { qualities }\end{array}$} & $\mathrm{r}$ & $0.482 * *$ & 0.88 & & & & & & & & \\
\hline & $\mathrm{N}$ & 177 & 340 & & & & & & & & \\
\hline \multirow{2}{*}{ C3 Project management } & $\mathrm{r}$ & $0.468^{* *}$ & $0.537^{* *}$ & 0.88 & & & & & & & \\
\hline & $\mathrm{N}$ & 243 & 316 & 464 & & & & & & & \\
\hline \multirow{2}{*}{$\begin{array}{l}\text { C4 Early Involvement of FM } \\
\text { providers }\end{array}$} & $\mathrm{r}$ & $0.359^{* *}$ & $0.464^{* *}$ & $0.461^{* *}$ & 0.88 & & & & & & \\
\hline & $\mathrm{N}$ & 216 & 286 & 405 & 422 & & & & & & \\
\hline \multirow{2}{*}{$\begin{array}{l}\text { C5 Involvement of owners and } \\
\text { users during construction phase }\end{array}$} & $\mathrm{r}$ & $0.323 * *$ & $0.403 * *$ & $0.436^{* *}$ & $0.419 * *$ & 0.74 & & & & & \\
\hline & $\mathrm{N}$ & 249 & 321 & 435 & 400 & 471 & & & & & \\
\hline \multirow{2}{*}{$\begin{array}{l}\text { C6 Early Involvement of } \\
\text { technical contractors }\end{array}$} & $\mathrm{r}$ & $0.319^{* *}$ & $0.496^{* *}$ & $0.409^{* *}$ & $0.369 * *$ & $0.258^{* *}$ & 0.78 & & & & \\
\hline & $\mathrm{N}$ & 243 & 305 & 428 & 394 & 424 & 449 & & & & \\
\hline \multirow{2}{*}{$\begin{array}{l}\text { C7 Involvement of owners and } \\
\text { users during early phase planning }\end{array}$} & $\mathrm{r}$ & $0.357^{* *}$ & $0.299 * *$ & $0.401^{* *}$ & $0.524^{* *}$ & $0.541 * *$ & 0.295 ** & 0.71 & & & \\
\hline & $\mathrm{N}$ & 257 & 306 & 437 & 401 & 445 & 420 & 480 & & & \\
\hline \multirow{2}{*}{ C8 Project objectives } & $\mathrm{r}$ & $0.398^{* *}$ & $0.306^{* *}$ & $0.230^{* *}$ & $0.402 * *$ & $0.318^{* *}$ & $0.377^{* *}$ & $0.281 * *$ & 0.82 & & \\
\hline & $\mathrm{N}$ & 154 & 164 & 218 & 206 & 220 & 218 & 222 & 247 & & \\
\hline \multirow{2}{*}{ C9 Project governance } & $\mathrm{r}$ & $0.502 * *$ & $0.425 * *$ & $0.412 * *$ & $0.413^{* *}$ & $0.380 * *$ & $0.360 * *$ & $0.511^{* *}$ & $0.474^{* *}$ & 0.75 & \\
\hline & $\mathrm{N}$ & 279 & 314 & 434 & 400 & 440 & 419 & 448 & 242 & 496 & \\
\hline \multirow{2}{*}{ C10 Contract strategy } & $\mathrm{r}$ & $0.293^{* *}$ & $0.442 * *$ & $0.403^{* *}$ & $0.346^{* *}$ & $0.280 * *$ & $0.390 * *$ & $0.261 * *$ & $0.465^{* *}$ & $0.428^{* *}$ & 0.78 \\
\hline & $\mathrm{N}$ & 255 & 298 & 401 & 366 & 408 & 391 & 406 & 236 & 425 & 447 \\
\hline $\mathrm{N}$ & & 302 & 340 & 464 & 422 & 471 & 449 & 480 & 247 & 496 & 447 \\
\hline Mean & & 4.34 & 4.41 & 4.85 & 3.82 & 4.44 & 4.14 & 4.68 & 3.69 & 4.68 & 4.26 \\
\hline SD & & 0.99 & 1.12 & 1.01 & 1.40 & 1.07 & 1.18 & 1.07 & 1.11 & 0.93 & 1.01 \\
\hline
\end{tabular}

Construct C1 Project outcomes has a slightly lower mean (4.34, SD 0.99) than C2 Completed building's qualities mean (4.41, SD 1.12). Thus, the respondents are slightly more satisfied with the completed buildings than with the project outcomes, but there is slightly more variation in the respondents' answers concerning the completed building than project outcomes. Construct C8 Project objectives (3.69, SD 1.11) and C4 Early involvement of FM providers (3.82, SD 1.40) have the lowest means.

Given the strength of $\mathrm{r}$, when comparing construct C3-C10's influences on construct $\mathrm{C} 1$ Project outcomes and construct $\mathrm{C} 2$ Completed building's qualities, the most important constructs concerning C1 Project outcomes are C2 Completed building' qualities, C7 Involvement of owners and users during early phase planning, C8 Project objectives and C9 Project governance. Table 6 similarly shows that given the strength of $r$, the most important constructs concerning C2 Completed building's qualities are C3 Project management, C4 Early involvement of FM providers, C5 Involvement of owners and users during construction phase, C6 Early involvement of technical contractors and C10 Contract strategy. However, the bivariate correlations (r) shown in Table 6 are not controlled for the effect of the other variables. Thus, relying on $r$ only to investigate how construct $\mathrm{C} 2, \mathrm{C} 7, \mathrm{C} 8$ and C9 influence construct C1 Project outcomes and how construct C3, C4, C5, C6 and C10 influence construct $\mathrm{C} 2$ Completed building's qualities might give misleading conclusions. Thus, further testing of the hypotheses is needed before we can draw any conclusions.

\subsection{Which Variables Are Most Important for the Project's Output and Short-Term Value Creation?}

To test H1A-E and to control for the effects of the different explanation factors on one another, we used a multiple regression model with $\mathrm{C} 2$ Completed building's qualities as the dependent variable. Table 7 shows the results of multiple regressions with C2 Completed 
building's qualities as the dependent variable, and C3 Project management, C4 Early involvement of FM providers, C5 Involvement of owners and users during construction phase, C6 Early involvement of technical contractors and C10 Contract strategy as the independent variables. This model explains $\left(\mathrm{r}^{2}\right) 48.7$ percent of the dependent variable $\mathrm{C} 2$ Completed building's qualities' variance.

Table 7. Multiple regression with project output C2 Completed building's qualities as dependent variable.

\begin{tabular}{|c|c|c|c|c|c|c|c|}
\hline IV & B (CI 95\%) & SE & Beta & $\mathbf{t}$ & $p$ & $\begin{array}{l}\text { Part } \\
\text { Corr. }\end{array}$ & VIF \\
\hline Constant & $0.047(-0.583-0.678)$ & 0.320 & & 0.147 & 0.883 & & \\
\hline C3 Project management & $0.322(0.185-0.460)$ & 0.070 & 0.274 & 4.613 & $<0.001$ & 0.217 & 1.58 \\
\hline $\begin{array}{l}\text { C6 Early involvement of } \\
\text { technical contractors }\end{array}$ & $0.199(0.095-0.303)$ & 0.053 & 0.216 & 3.757 & $<0.001$ & 0.177 & 1.49 \\
\hline $\begin{array}{l}\text { C4 Early involvement of FM } \\
\text { providers }\end{array}$ & $0.105(0.014-0.197)$ & 0.047 & 0.130 & 2.263 & 0.025 & 0.107 & 1.48 \\
\hline C10 Contract strategy & $0.214(0.092-0.335)$ & 0.062 & 0.193 & 3.459 & $<0.001$ & 0.163 & 1.40 \\
\hline $\begin{array}{l}\text { C5 Involvement of owners and } \\
\text { users during construction phase }\end{array}$ & $0.139(0.023-0.254)$ & 0.059 & 0.133 & 2.366 & 0.019 & 0.112 & 1.43 \\
\hline
\end{tabular}

In this case, all the independent variables shown in Table 7 are significant. In other words, hypotheses H1A Project management is positively related to the completed building's qualities holds when controlled for the other independent variables in the model. Hypothesis H1B Early involvement of technical contractors is positively related to the completed building's qualities, hypothesis H1C Early involvement of FM providers is positively related to the completed building's qualities, hypothesis H1D Having a contract strategy is positively related to the completed building's qualities, and hypothesis H1E Owner and user involvement during the construction phase is positively related to the completed building's qualities hold when controlled for the other independent variables in the model.

The regression model has been validated through 10,000 random bootstrap samples from the initial sample. This bootstrapping validated the model because B C3's 95 percent CI was between 0.159 and 0.482 , B C6's CI was between 0.093 and 0.309 , B C4's CI was between 0.014 and $0.196, \mathrm{~B}$ C10's CI was between 0.083 and 0.352 and B C5's CI was between 0.020 and 0.262 . Thus, none of these CIs included zero, and the bootstrapping $p$-values for B C3, C6, C4, C10 and C5 respectively were $<0.001,<0.001,0.014,0.001$ and 0.026.

Multicollinearity, i.e., perfect linear relationships between the variables, can be a problem in multiple regressions. The variance inflation factor (VIF) is a common measure of indications of multicollinearity. The rule of thumb, according to Field [56] (pp. 325-326), is that a VIF larger than 10 is "cause for concern", and an average VIF "substantially greater than 1" can indicate biased regressions. Thus, given Field's rule of thumb, Table 7 gives no indications of multicollinearity. Thus, there are good reasons to trust the findings from the multiple regression model concerning hypotheses $\mathrm{H1A}, \mathrm{H} 1 \mathrm{~B}, \mathrm{H} 1 \mathrm{C}, \mathrm{H} 1 \mathrm{D}$ and $\mathrm{H} 1 \mathrm{E}$, about positive relations between $\mathrm{C} 2$ Completed building's qualities and project management, early involvement of technical contractors, early involvement of FM providers, contract strategy and involvement of owners and users during the construction phase.

Table 7 also shows the part correlation, which is a measure of the unique relationships between each independent variable and the dependent variable [56] (p. 341), i.e., the net effect of each independent variable on the dependent variable controlled for the effect of the other independent variables. The part correlation is usually significantly smaller than the zero-order correlation (The standardized Beta in Table 7 is almost equal to $r$ in Table 6). In Table 7 the part correlation varies from 0.217 for C3 Project management to 0.107 for C4 Early involvement of FM providers. Thus, when controlling for the other 
independent variables included in the model, C3 Project management have most influence on C2 Completed building's qualities and C4 Early involvement of FM-providers have least influence on C2 Completed building' qualities.

\subsection{Which Variables Are Most Important for the Project's Outcomes and Long-Term Value Creation?}

To test whether the Hypotheses 2A-D concerning long-term value creation hold when controlled for other explanation factors, we also undertook a multiple linear regression analysis with C1 Project outcome as dependent variable and C9 Project governance, C2 Completed building's qualities, C8 Project objectives and C7 Involvement of owners and users during early phase planning as independent variables. Table 8 shows the results of a multiple regression with $\mathrm{C} 1$ Outcome as dependent variable. This model explains $\left(\mathrm{r}^{2}\right) 51.6$ percent of the dependent variable's variance.

Table 8. Multiple regression with C1 Project outcome as dependent variable.

\begin{tabular}{cccccccc}
\hline IV & B (CI 95\%) & SE & Beta & t & $p$ & $\begin{array}{c}\text { Part } \\
\text { Corr. }\end{array}$ & VIF \\
\hline Constant & $\begin{array}{c}-0.332 \\
(-1.328-0.663)\end{array}$ & 0.501 & & -0.664 & 0.509 & & \\
\hline C9 Project governance & $0.363(0.118-0.607)$ & 0.123 & 0.286 & 2.953 & 0.004 & 0.219 & 1.71 \\
\hline C2 Completed building's & $0.366(0.205-0.528)$ & 0.081 & 0.372 & 4.504 & $<0.001$ & 0.334 & 1.24 \\
\hline $\begin{array}{c}\text { qualities } \\
\text { C8 Project objectives }\end{array}$ & $0.149(-0.026-0.324)$ & 0.088 & 0.147 & 1.698 & 0.093 & 0.126 & 1.36 \\
\hline $\begin{array}{c}\text { C7 Involvement of owners and } \\
\text { users during early phase } \\
\text { planning }\end{array}$ & $0.188(0.063-0.275)$ & 0.083 & 0.192 & 2.251 & 0.027 & 0.167 & 1.33 \\
\hline
\end{tabular}

Table 8 shows that all independent variables except C8 Project objectives are significant. Thus, Hypothesis H2A Project governance is positively related to the completed building's long-term value-creation holds when controlled for the model's other explanation factors. That is also the case for Hypothesis H2B The completed building's qualities are positively related to the completed building's long-term value creation and hypothesis H2D Involvement of owners and users in early phase planning is positively related to the completed building's long-term value creation holds. However, Hypothesis H2C Project objectives are positively related to the completed building's long-term value creation does not hold when controlled for other explanation factors, even if C8 includes questions about environmental requirements, innovations, life cycle costs, tenant costs and co-location of actors in the project phases, which may have positive influence on a building project's outcome.

Even this model was validated through 10,000 random bootstrap samples from the initial sample. The bootstrapping validated even this model because B C9's 95 percent CI was between 0.131 and 0.621, B C2's CI was between 0.140 and 0.549 , B C8's CI was between -0.038 and 0.338 which includes zero, and B C7's CI was between 0.029 and 0.370 . Thus, bootstrapping confirmed that B C8's CI included zero, which indicates B C8 is not significant, while the other constructs' B CIs do not include zero, which indicates that B C9, $\mathrm{C} 2$ and $\mathrm{C} 7$ are significantly different from zero. The bootstrapping $p$-values for $\mathrm{B} C 9, \mathrm{C} 2$, C8, C10 and C7 respectively were $0.005,0.001,0.126$, and 0.033 .

In this regression model there are also no problems with multicollinearity, because VIF is around 1. Table 8 also shows the part correlation, which varies from 0.334 for C2 Completed Building' qualities to 0.126 for C8 Project objectives. Thus, C2 Completed Building's qualities has the most influence on C1 Outcome, and C8 Project objectives has least influence on $\mathrm{C} 1$ Project outcome when controlled for the other independent variables included in the multiple regression model. 
Thus, the most important factors for a building project's outcome or positive effects for owners and users when controlling for the other factors are C2 Completed building' qualities, C9 Project governance and C7 Involvement of owners and users during early phase planning.

\subsection{What Matters for Short-Term and Long-Term Value Creation?}

In Section 1.2 we derived several hypotheses from the two research questions. In Section 3.3 and Section 3.4 we tested these hypotheses. For a better overview, we have summarized the results in Table 9.

Table 9. Hypothesis testing results.

\begin{tabular}{|c|c|c|}
\hline \multicolumn{3}{|c|}{ Short-Term Value Creation } \\
\hline & Hypothesis & Result \\
\hline $\mathrm{H} 1 \mathrm{~A}$ & $\begin{array}{c}\text { Project management is positively related to the completed } \\
\text { building's qualities. }\end{array}$ & Supported \\
\hline H1B & $\begin{array}{l}\text { Early involvement of technical contractors is positively } \\
\text { related the completed building's qualities. }\end{array}$ & Supported \\
\hline $\mathrm{H} 1 \mathrm{C}$ & $\begin{array}{l}\text { Early involvement of FM providers is positively related to } \\
\text { the completed building's qualities. }\end{array}$ & Supported \\
\hline H1D & $\begin{array}{l}\text { Having a contract strategy is positively related to the } \\
\text { completed building's short-term qualities. }\end{array}$ & Supported \\
\hline H1E & $\begin{array}{l}\text { Involvement of owners and uses during the construction } \\
\text { phase is positively related to the completed building's } \\
\text { qualities. }\end{array}$ & Supported \\
\hline \multicolumn{3}{|c|}{ Long-Term Value Creation } \\
\hline $\mathrm{H} 2 \mathrm{~A}$ & $\begin{array}{l}\text { Project governance is positively related to the completed } \\
\text { building's long-term value-creation. }\end{array}$ & Supported \\
\hline $\mathrm{H} 2 \mathrm{~B}$ & $\begin{array}{l}\text { The completed building's qualities are positively related to } \\
\text { the completed building's long-term value creation. }\end{array}$ & Supported \\
\hline $\mathrm{H} 2 \mathrm{C}$ & $\begin{array}{l}\text { Project objectives are positively related to the completed } \\
\text { building's long-term value creation. }\end{array}$ & $\begin{array}{c}\text { Not } \\
\text { supported }\end{array}$ \\
\hline $\mathrm{H} 2 \mathrm{D}$ & $\begin{array}{l}\text { Involvement of owners and users in early phase planning is } \\
\text { positively related to the completed building's long-term } \\
\text { value creation. }\end{array}$ & Supported \\
\hline
\end{tabular}

These results seem to support most expectations about the connection between explanation factors and results. On the surface, given what we know about building projects, the factors that determine the output and outcome seem plausible. However, hypothesis $\mathrm{H} 2 \mathrm{C}$ is not supported. We will investigate further the realities behind these results in the discussions that follow.

\section{Discussion}

The study is oriented towards identifying the facilitators that facilitate value creation for the various stakeholders involved in building projects, hereunder facility managers These factors include project owners' as well as project managers' efforts to establish effective project governance and project management. These efforts must balance the various stakeholders' short term and long-term objectives. From the literature, we have observed that value orientation is broadly mentioned in the construction field, but that findings may point in different directions and this may be a problem for practical implementation. Our analysis of a large empirical material highlights which concrete parameters practitioners perceive as important. 
Our discussion is designed to answer the two research questions, based on the theoretical background and empirical part: Which factors are most important for the building project's output or short-term value creation, i.e., the project's time, cost, and the completed building's qualities? Which factors are most important for the building project's outcome or long-term value creation, i.e., the completed building's effect for owners and users? Thus, this section has two parts accordingly.

\subsection{Factors That Facilitate Project Output and Short-Term Value Creation for Building Owners and Users}

This paper has hopefully contributed to clarification and operationalisation of value creation, and even such as requested by van der Voordt and Jensen [6] (p. 328) contributed to clarification and operationalisation of the concept added value. Project output represents the short-term perspective on value creation-what the project actually delivers. From the literature review, we found that many authors emphasised short-term value creation parameters, such as: achieving client's tangible and intangible criteria [39], better communication, better management, and early contractor involvement [30,47]. We also note that project governance as a regulatory framework influences strategy and project output and performance measurements [24,28,34]. All these conclusions find support in this analysis.

This analysis also shows similarities with other findings from literature. C3 Project management priorities are important in the early phase, planning and design phase, and in the construction phase, as previously indicated by Leiringer and Bröchner [45], Hjelmbrekke et al. [24] and Haddadi et al. [19].

Differently from the literature, our respondents' perception of the FM providers' involvement in the early phase was among the least important, given the part correlation shown in Table 7. Did the respondents indicate status quo (as it is) rather than how it should be? In hindsight, we cannot eliminate this interpretation. Highly experienced individuals may continue to do what they always have done and find arguments as to why this should continue. Authors once again emphasize the importance of changing focus from cost efficiency to added value [45] and from product delivery to creation of value design and value production [25]. The early phase is the first important planning phase to establish foundations for value creation.

We find it very interesting to note from the analysis that five short-term oriented factors appeared as significant for the output, four of them from the project management perspective (C3 Project management priorities, C6 Early involvement of technical contractors, C10 Contract strategy, and C4 Early involvement of FM providers) and one from the governance perspective (C5 Involvement of owners and users during construction phase).

Further, the respondents perceive C6 Early involvement of technical contractors as one of the most significant measures in the early phase. In practice, it is usual to start a direct communication with a technical contractor in the construction phase, but in this study the respondents answered that to create value a technical contractor is a key person to be involved in all phases, starting from the early phase. It is possible that respondents see technical contractors as bringing innovative contributions. However, Wondimu et al. (2018) found that public procurement regulations may prevent early involvement of technical contractors. Rules and regulations concerning public procurements may thus in worst case also represent an obstacle against innovation. Innovation itself is one of the items in C8 Project objectives in our analysis. We also note the current trend to call for early contractor involvement but find it especially interesting that the focus here is on technical contractors. One potential explanation may be the increasing amount of complex technical solutions and systems integrated in buildings (smart buildings, etc.). This role may actually become more important.

In the literature review, for value creation the need for owner and user involvement from the early phase was mentioned many times, i.e., "fulfilment of the user's needs" and "fulfilment of owner's and corporate strategy" [19], or to recognize customer expectation in pre-design phase $[31,32,43]$. The respondents' perception seems slightly different. The analysis indicates they do not perceive the importance of C7 Involvement of owners and 
users during early phase planning for C2 Completed building's qualities (output) as most important. This can be explained by practical experience, such that that owners and users do not have the technical competence needed to take part in discussions about the output. The questionnaire may not have identified this nuance. We interpret these results to indicate there is still a gap between theory and practice and may indicate that what it takes to achieve value creation in building projects is not fully understood, neither in theory nor in practice.

\subsection{Factors That Facilitate Project Outcome and Long-Term Value Creation for Building Owners and Users}

Project outcome represents the long-term perspective on value creation, as indicated by, among others, Jensen's [17] FM Value Map. From the literature review, we find that many authors emphasised long-term value creation parameters, such as stakeholder benefits [11], achieving client's tangible and intangible criteria [39], changing focus to added value orientation [45] and strategic performance [44]. Further, understanding the client's goals and involvement from the early phase [20,31,32,43,44], defining project value [24] and better contractual relation [52]. Among the Norwegian respondents, such as shown in Section 3.4, only three factors were significantly important for creating value for the project outcome: C2 Completed building' qualities, C9 Project governance, and C7 Involvement of owners and users during early phase planning.

Returning to the hypothesis that was not supported, H2C Project objectives are positively related to the completed building's long-term value creation. Some of the priorities in C8 Project objectives are mostly governance oriented (Environmental requirements, Life Cycle Cost, the building owner's willingness to invest in innovations, and Competitive tenant costs). Two of them (Environmental requirements and LCC) are expected and in accordance with the sustainable orientation of the European and Norwegian building sector and society, for instance, through Horizon 2020, EERA, and BREEAM, etc. The new finding is the respondents' perception of willingness to invest in innovation. This, in combination with Competitive tenant costs, may indicate that building owners should be interested in smart and innovative solutions and not only cutting costs, because smart and innovative solutions may increase the value of buildings. The other important and interesting finding seen from the project governance perspective is co-location of actors in the project phases, which is one of the items in C8 Project objectives. Such co-location may facilitate cooperation and co-creation, and thereby contribute to establishment of outcome focus.

According to Table 6, there is a significant and medium strong bivariate effect ( $\mathrm{r}=0.398, p=0.01$ ) between C1 Project outcomes and C8 Project objectives. However, when controlling for the other variables in the multivariate regression model C8 Project objectives were not significant contributors to project outcome and long-term value creation for building owners and users, and this finding was confirmed by the bootstrapping validation of the model. One possible explanation of this counter-intuitive finding that C8 Project objectives is not a significant explanation of the project's outcome, indicated by the high number of "Don't know / Not relevant" answers in the questions included in C8, namely 97 "Don't know / Not relevant" answers in the question about environmental requirements (certification of the finished building), 78 in the question about the building owner's willingness to invest in innovations, 97 in the question about life cycle costs, and 243 in the question about competitive tenant costs and 96 in the question about co-location of actors in the project phases. It is also worth noting that many of the "Don't know/Not relevant" answers were given by consulting engineers, building owners and the building owners' project managers. The particularly high number of "Don't know / Not relevant" answers (243) in the question concerning competitive tenant costs may be a consequence of the fact that particularly financially oriented building owners would like to maximise their rental incomes. If the income approach is used to estimate the buildings' value, such as described by among others RICS' IVS [8] and TEGOVA's EVS [9], the net rental income is very important for buildings' value as collateral for mortgages and for buildings' resale 
value. Thus, there are good reasons to assume that many building owners carefully monitor their buildings' net rental income. The building owners' emphasis on net rental income may influence the building users' outcome of building or renovation projects.

C9 Project governance is also intriguing. It is hard, even for professionals, to keep a clear division between project management and project governance perspectives. Description and functional requirements from the early phase, building owner and project manager's competencies and experience and user involvement have high priority. In literature we found many contributions that indicate those priorities or characteristics [24,25,28,29,31-33], but terms such as strategies, goals and value creation may be somewhat alienating to practitioners. Therefore, we were positively surprised that in practice the benefit from the early-phase requirements and user involvement is highly recognised. Owner's experience is seen as a significant factor for long-term value creation priority.

In the bigger picture, this may be interpreted as confirmation of the idea that practitioners think "governors should govern, and managers should manage". Owners need to make clear priorities supporting long-term value creation, but, as seen in Section 4.1, users and owners may not have the technical competence to actively engage in the technical debates on the outcome. From the analysis results, it seems that practitioners think this should be left to technical experts. Knowing that buildings are becoming even more technically advanced, and acknowledging the tendency to promote more integrated processes, this may seem either as a warning that the emerging trend will meet serious challenges in this field, or that we should see an upcoming rise in initiatives to increase the technical knowledge among building owners and users.

\subsection{Generalisation of Results}

This analysis is based on a large dataset from Norway and is highly representative for the Norwegian context. Even if the sampling is not randomized, it mirrors the situation in Norwegian construction industry and building projects. The uniform context gives some limitations for generalization. It is likely to be difficult to transfer some of the findings to countries in regions with a different economic situation and judicial framework. The level of professionalization is considered high in Norway, so it is reasonable to assume these results also will be valid in other countries with the same level of professionalism. Thus, there are good chances of finding similar tendencies in other western countries as shown in the findings and discussions in this paper.

\section{Conclusions}

Norwegian respondents perceived some priorities of project governance and project management as significant for value creation. To facilitate value creation for the various stakeholders involved in building projects, project owners and project managers must establish project governance and project management that balance the various stakeholders' long-term and short-term objectives.

\subsection{Which Factors Are Most Important for the Project Output (Short-Term Result), i.e., the} Qualities of the Completed Building?

Short-term value creation means maximizing the potential for future value creation. The analyses confirm that practitioners see project management priorities and early involvement of technical contractors as most important. Contract strategy and owner and user involvement during construction phase are also significant. Early involvement of FM providers was found less important, but still significant for the project output. This finding is important for facility managers who become involved in building or renovation projects.

The authors find the technical contractors' importance-from the early phase through the planning and construction phases-especially interesting and puzzling. We understand the technical contractors' importance for the innovative outputs, and an indication of current development in construction towards higher levels of technical complexity. Seeing this together with long-term value creation priorities, such as the building owner's willingness 
to invest in innovations, and competitive tenant costs, it means that Norwegian respondents assume that technical contractors can bring in new knowledge and experience and thereby contribute to innovation and value creation, at least in the short time perspective.

5.2. Which Factors Are Most Important for the Building Project's Outcome and Long-Term Value Creation, i.e., the Effect of the Building for Owners and Users?

Long-term value creation is the ultimate realization of the building's potential for users and owners, and even its contribution to society. Long-term value creation depends primarily on the qualities of the building itself, on project governance, and involvement of owners and users during early phase planning. Governance needs to define a framework for development that from the start put long-term value creation at the very forefront of development. Thus, it is also natural that owners and users' involvement in the early phase planning is confirmed as significant. However, when controlling for the other explanation factors the project owner's project objectives were not significant, even if correlation analysis indicates that project objectives contribute positively to the achievement of project outcomes.

This paper's analyses show it is neither governance alone, nor project management separated from governance, but the adequate combination of governance and management elements that can secure maximum value creation for building owners and users. Thus, the analyses have identified success factors and enablers for value creation seen from a combined governance and management perspective. To put it short: facilitation of value creation in building or renovation projects is all about having the right focus and involving the right parties at the right time. This finding is of great importance among others for facility managers and real estate developers. Another take-home message from this paper is that facility managers who get involved in building or significant renovation projects should be aware of consulting engineers who might be more concerned with the process and the output of the building process, than the outcome. If involved in in building or renovation projects, facility managers should also be aware of financially oriented building owners and their project managers that might be more concerned with the building's financial value than the building's contribution to the demand organisation's value creation.

During the analysis, we also noticed there is a gap between theory and practice. Neither academia nor practitioners have still developed adequate concepts and understanding to achieve value creation in building and renovation projects. Questions for further research are among others project objectives' importance for building and renovation project's long-term value creation. Management research (work psychology, business strategy, etc.) have for decades established that objectives usually facilitate obtainment of goals, but in this paper, when controlled for other explanation factors, project objectives had no significant effect on building projects' outcomes. Even if this paper has indicated some possible explanations, this puzzle requires further investigation. Another future research question is the implications in building and renovation projects for project governance and project management because of the buildings' increasing technical complexity (smart buildings, etc.). A third research question is how to develop rules and regulations of public procurements that facilitate innovation in building projects, such as early involvement of technical contractors and FM-providers.

Author Contributions: Conceptualization, K.B., A.H., O.J.K. and A.T.S.; methodology, K.B., A.H. and A.T.S.; validation, K.B., A.H. and A.T.S.; formal analysis, K.B. and A.T.S.; investigation, K.B., A.H. and A.T.S.; data curation, K.B.; writing-original draft preparation, K.B., A.H., O.J.K. and A.T.S.; writing-review and editing, K.B., A.H., O.J.K. and A.T.S.; visualization, K.B.; supervision, O.J.K. and A.T.S.; project administration, K.B. All authors have read and agreed to the published version of the manuscript.

Funding: This research was funded by The Research Council of Norway, grant number 2352940/O30.

Institutional Review Board Statement: Not applicable. 
Informed Consent Statement: Informed consent was obtained from all subjects involved in the study.

Data Availability Statement: Data are available on request from the corresponding author.

Acknowledgments: The authors thank all the respondents and the reviewers.

Conflicts of Interest: The authors declare no conflict of interest.

\section{References}

1. NS-EN15221-1:2006. Facility Management Part 1: Terms and Definitions; Standards Norway: Lysaker, Norway, 2007.

2. ISO 41011:2017(E). Facility Management Vocabulary; The International Organization for Standardization: Geneva, Switzerland, 2017.

3. Introduction and Overall Framework. In Facilities Management and Corporate Real Estate Management and Value Drivers; Jensen, P.A.; van der Voordt, T. (Eds.) Routledge: Oxford, UK; New York, NY, USA, 2017; pp. 3-13.

4. den Heijer, A.; de Jonge, H. Linking Decisions and Performance: Adding Value Theories Applied to the University Campus. In The Added Value of Facilities Management Concepts, Findings and Perspectives; Jensen, P.A., van der Voordt, T., Coenen, C., Eds.; Polyteknisk Forlag: Lyngby, Denmark, 2012; pp. 177-194.

5. den Heijer, A. Managing University Campuses-In Theory and Practice. In Dear is Durable: Liber Amicorum for Hans de Jonge; Arkesteijn, M., van der Voordt, T., Remøy, H., Chen, Y., Curvelo Magdaniel, F., Eds.; TU Delft Open: Delft, The Netherlands, 2016; pp. 161-170.

6. Reflections, Conclusions and Recommendations. In Facilities Management and Corporate Real Estate Management as Value DriversHow to Manage and Measure Adding Value; van der Voordt, T.; Jensen, P.A. (Eds.) Routledge: London, UK; New York, NY, USA, 2017; pp. 323-333.

7. Geltner, D.M.; Miller, N.G.; Clayton, J.; Eichholtz, P. Commercial Real Estate Analysis and Investments, 3rd ed.; On Course Learning: Mason, WI, USA, 2014.

8. International Valuation Standards Council. International Valuation Standards (IVS) Effective 31 January 2020; International Valuation Standards Council: London, UK, 2019.

9. TEGOVA. European Valuation Standards—2020, 9th ed.; TEGOVA Secretariat: Brussels, Belgium, 2020.

10. FM and CREM Interventions. In Facilities Management and Corporate Real Estate Management and Value Drivers; Jensen, P.A.; van der Voordt, T. (Eds.) Routledge: Oxford, UK; New York, NY, USA, 2017; pp. 14-28.

11. Atkinson, R. Project management: Cost, time and quality, two best guesses and a phenomenon, it's time to accept other success criteria. Int. J. Proj. Manag. 1999, 17, 337-342. [CrossRef]

12. Jensen, P.A.; van der Voordt, T.; Coenen, C.; von Felten, D.; Sarasoja, A.-L.; Nielsen, S.B.; Riratanaphong, C.; Pfenninger, M. The Concept of Added Value of FM. In The Added Value of Facilities Management Concepts, Findings and Perspectives; Jensen, P.A., van der Voordt, T., Coenen, C., Eds.; Polyteknisk Forlag: Lyngby, Denmark, 2012; pp. 58-74.

13. Vrijhoef, R.; Koskela, L.J. A Critical Review of Construction as a Project-Based Industry: Identifying Paths Towards a Projectindependent Approach to Construction. In CIB Symposium, Combining Forces, Advancing Facilities Mangement E Construction through Innovation Series; Kähkönen, K., Ed.; Proceedings CIB Combining Forces: Helsinki, Finland, 2005; pp. 13-24.

14. Vrijhoef, R.; Koskela, L.J. Revisiting the Three Peculiarities of Production in Construction; University of Salford: Manchester, UK, 2005.

15. McKinsey. Reinventing Construction: A Route to Higher Productivity; McKinsey's Capital Projects \& Infrastructure Practice McKinsey Global Institute: New York, NY, USA, 2017.

16. Turner, R.; Zolin, R. Forecasting Success on Large Projects: Developing Reliable Scales to Predict Multiple Perspectives by Multiple Stakeholders over Multiple Time Frames. Proj. Manag. J. 2012, 43, 87-99. [CrossRef]

17. Jensen, P.A. The Facilities Management Value Map: A conceptual framework. Facilities 2010, 28, 175-188. [CrossRef]

18. Womack, J.P.; Jones, D.T. Lean Thinking: Banish Waste and Create Wealth in Your Corporation; Touchstone: New York, NY, USA, 1996.

19. Haddadi, A.; Johansen, A.; Andersen, B. A conceptual Framework to Enhance value Creation in Construction projects. International Conference on project Management. Procedia Comput. Sci. 2016, 100, 565-573. [CrossRef]

20. Haddadi, A.; Temeljotov-Salaj, A.; Foss, M.; Klakegg, O.J. The Concept of Value for Owners and Users of Buildings-A Literature Study of Value in Different Contexts. Procedia Soc. Behav. Sci. 2016, 226, 381-389. [CrossRef]

21. Laursen, M.; Svejvig, P. Taking stock of project value creation: A structured literature review with future directions for research and practice. Int. J. Proj. Manag. 2016, 34, 736-747. [CrossRef]

22. Chan, A.P.C.; Chan, A.P.L. Key performance indicators for measuring construction success. Benchmark. Int. J. 2004, 11, $203-221$. [CrossRef]

23. Arge, K.; Hjelmbrekke, H. Value enhancing processes in building and real estate. In Proceedings of the Joint CIB W70, W092 Conference, Cape Town, South Africa, 23-25 January 2012.

24. Hjelmbrekke, H.; Hansen, G.K.; Lohne, J. A Motherless Child-Why do Construction Projects Fail. Procedia Econ. Finance 2015, 21, 72-79. [CrossRef]

25. Bjørberg, S.; Larssen, A.K.; Temeljotov Salaj, A.; Haddadi, A. Optimizing building design to contribute to value creation. In Proceedings of the IPMA 29th World Congress, Westin Playa Bonita, Panama, 28-30 September 2015.

26. Davis, K. Different stakeholder groups and their perceptions of project success. Int. J. Proj. Manag. 2014, 32, 189-201. [CrossRef]

27. Munns, A.; Bjeirmi, B. The role of project management in achieving project success. Int. J. Proj. Manag. 1996, 14, 81-87. [CrossRef] 
28. Ahola, T.; Ruuska, I.; Artto, K.; Kujala, J. What is project governance, and what are its origins? Int. J. Proj. Manag. 2014, 32, 1321-1332. [CrossRef]

29. Badewi, A. The impact of project management (PM) and benefits management (BM) practices on project success: Toward developing a projects benefits governance framework. Int. J. Proj. Manag. 2016, 34, 761-778. [CrossRef]

30. Musawir, A.U.; Serra, C.E.M.; Zwikael, O.; Ali, I. Project governance, benefit management, and project success: Towards a framework for supporting organizational strategy implementation. Int. J. Proj. Manag. 2017, 35, 1658-1672. [CrossRef]

31. Boge, K.; Salaj, A.T. Practice vs theory: Short-term financials trumps long-term value creation. J. Corp. Real Estate 2017, 19, 186-204. [CrossRef]

32. Boge, K.; Temeljotov Salaj, A.; Bjørberg, S.; Larssen, A.K. Failing to plan-Planning to fail: How early phase planning can improve building's lifetime value creation. Facilities 2018, 36, 49-75. [CrossRef]

33. Hjelmbrekke, H.; Klakegg, O.J.; Lohne, J. Governing value creation in construction project: A new model. Int. J. Manag. Proj. Bus. 2017, 10, 60-83. [CrossRef]

34. Klakegg, O.J.; Lichtenberg, S. Successive Cost Estimation-Successful Budgeting of Major Projects. Procedia Soc. Behav. Sci. 2016, 226, 176-183. [CrossRef]

35. Nasar, J.L. Urban Design Aesthetics. Environ. Behav. 1994, 26, 377-401. [CrossRef]

36. Winch, G.M. Managing Construction Projects, 2nd ed.; Wiley-Blackwell: Oxford, UK, 2014.

37. Paden, R. Values and Planning: The Argument from Renaissance Utopianism. Ethic Place Environ. 2001, 4, 5-30. [CrossRef]

38. Shenhar, A.J.; Dvir, D. Reinventing Project Management: The Diamond Approach to Successful Growth and Innovation; Harvard Business School Press: Boston, MA, USA, 2007.

39. Chan, A.P.C.; Scott, D.; Lam, W.M. Framework of Success Criteria for Design/Build Projects. J. Manag. Eng. 2002, 18, 120-128. [CrossRef]

40. How Buildings Add Value for Clients; Spencer, N.C.; Winch, G. (Eds.) Thomas Telford: London, UK, 2002.

41. Morris, P.W.G. Science, objective knowledge and the theory of project management. Civ. Eng. 2002, 150, 82-90. [CrossRef]

42. Breese, R. Benefits realisation management: Panacea or false dawn? Int. J. Proj. Manag. 2011, 30, 341-351. [CrossRef]

43. Hjelmbrekke, H.; Klakegg, O.J. The new common ground: Understanding value. In Proceedings of the 7th Nordic Conference on Construction Economics and Organisation, Trondheim, Norway, 12-14 June 2013; pp. 269-281.

44. Samset, K. Early Project Appraisal: Making the Initial Choices; Palgrave Macmillan: New York, NY, USA, 2010.

45. Leiringer, R.; Bröchner, J. Editorial: Service-led construction projects. Constr. Manag. Econ. 2010, 28, 1123-1129. [CrossRef]

46. Gottlieb, S.C.; Haugbølle, K. Contradictions and collaboration: Partnering in-between systems of production, values and interests. Constr. Manag. Econ. 2013, 31, 119-134. [CrossRef]

47. Reifi, M.H.E.; Emmitt, S. Perceptions of lean design management. Arch. Eng. Des. Manag. 2013, 9, $195-208$.

48. Wondimu, P.A.; Hosseini, A.; Lohne, J.; Laedre, O. Early contractor involvement approaches in public procurement. J. Public Procure. 2018, 18, 355-378. [CrossRef]

49. Klakegg, O.J.; Shannon, D. Board of Directors' Responsibility for Construction Projects. In Proceedings of the 7th Nordic Conference on Construction Economics and Organisation, Trondheim, Norway, 12-14 June 2013; pp. 257-268.

50. Crawford, L.; Cooke-Davies, T.; Hobbs, B.; Labuschagne, L.; Remington, K.; Chen, P. Governance and Support in the Sponsoring of Projects and Programs. Proj. Manag. J. 2008, 39, S43-S55. [CrossRef]

51. Griffiths, F. Project contract strategy for 1992 and beyond. Int. J. Proj. Manag. 1989, 7, 69-83. [CrossRef]

52. Suprapto, M.; Bakker, H.L.; Mooi, H.G.; Hertogh, M.J. How do contract types and incentives matter to project performance? Int. J. Proj. Manag. 2016, 34, 1071-1087. [CrossRef]

53. Watermeyer, R.B. A framework for developing construction procurement strategy. Proc. Inst. Civil Eng.-Manag. Procure. Law 2012, 165, 223-237. [CrossRef]

54. Gerring, J.; Christenson, D. Applied Social Science Methodology: An Introductory Guide; Cambridge University Press: Cambridge, UK, 2017.

55. Hair, J.F.; Clack, W.C.; Babin, B.J.; Anderson, R.E. Multivariate Data Analysis, 7th ed.; Pearson New International Edition; Pearson Education Limited: Harlow, UK, 2014.

56. Field, A. Discovering Statistics Using IBM SPSS Statistics, 4th ed.; Sage Publications: London, UK, 2013.

57. Cohen, J. Statistical Power Analysis for the Behavioral Sciences, 2nd ed.; Lawrence Erlbaum Associates: Hillsdale, NJ, USA, 1988. 